\title{
Wealth and consumption inequality: an interquantile analysis
}

Juan Ignacio Martín-Legendre, Pablo Castellanos-García and

\begin{abstract}
Purpose - The purpose of this paper is to analyze the changes in wealth and consumption inequality in Spain and estimate the consumption effects of housing and financial wealth.

Design/methodology/approach - The estimations are made using micro-data from the Spanish Survey of Household Finances (2002-2014) applying cross-section, panel and interquartile techniques.

Findings - The findings of this paper suggest that there was an increase in wealth inequality during the period under analysis and a reduction in consumption inequality. Also, the authors find a significant positive effect of wealth on consumer expenditure. Disaggregating by asset type, the value of the main residence is the category with the highest estimated effect on consumption, whereas the remaining types of assets, although still positive and generally significant, have more modest effects on consumption. However, the estimated coefficients and their significance can change substantially depending on the phase of the economic cycle and the position of the household in the income distribution.

Originality/value - These results provide new empirical evidence on the effects of household wealth changes on their consumption behavior, the differences depending on the household's position in the distribution and the fluctuations of these estimated coefficients throughout a period of profound economic upheavals.
\end{abstract}

Keywords Inequality, Consumption, Survey data, Wealth effect, Interquartile regressions

Paper type Research paper

\section{Introduction}

The collapse in both output and household consumption that took place in Spain in the wake of the last global economic crisis was so deep and persistent that, according to OECD data, pre-crisis levels had not yet been recovered by 2016. Throughout the five years that the recession lasted, gross domestic product (GDP) per capita fell by $10.6 \%$ and private consumption expenditure per capita shrank by $15.2 \%$, breaking with a growth streak that dated back to the early 1990s.

(C) Juan Ignacio Martín-Legendre, Pablo Castellanos-García and José Manuel Sánchez-Santos. Published in Applied Economic Analysis. Published by Emerald Publishing Limited. This article is published under the Creative Commons Attribution (CC BY 4.0) licence. Anyone may reproduce, distribute, translate and create derivative works of this article (for both commercial and noncommercial purposes), subject to full attribution to the original publication and authors. The full terms of this licence may be seen at http://creativecommons.org/licences/by/4.0/legalcode

JEL classification - D31, E21

Funding: This research was funded by the Consellería de Cultura, Educación e Ordenación Universitaria, Xunta de Galicia (ED481A-2016/356) and the Ministerio de Economía, Industria y Competitividad (Project CSO2017-86178-R).
Wealth and consumption inequality 
AEA

28,83
At the same time, in the period between the first quarter of 2002 and the third quarter of 2007 , real house prices increased by $81.7 \%$, while share prices rose by $107.8 \%$ in the same period. Since that quarter, there were falls in both variables that continued for several years.

There is a wide range of research work on the macroeconomic implications of wealth fluctuations such as those experienced by Spanish households over the past two decades. Both the immense magnitude of the Spanish boom-and-bust cycle and the high rate of homeownership - around 80\% - make it particularly appropriate to analyze the relationship between this wealth revaluation and devaluation and private consumption.

For this purpose, we will use the micro-data from the Encuesta Financiera de las Familias (Survey of Household Finances) (henceforth, EFF). This survey provides wealth and consumption data for a representative sample of households, which ensures the reliability of the results, as well as a set of demographic variables, which allows controlling for other factors (e.g. age, household size or educational level) that might be relevant to explain household consumption.

However, given that the estimated elasticities for a data set as broad and heterogeneous as the one provided by the EFF may vary depending on the position of a certain household in the distribution, we decided to perform interquartile regressions to determine the extent of the differences (if any) in the estimated coefficients.

Despite the plentiful literature regarding the relationship between exogenous changes in households' wealth and their consumption behavior, to our best knowledge, there is only one major study that attempts to explore the wealth effect for the Spanish economy using microdata (Bover, 2005). Considering the time elapsed since the publication of this study and the vast amount of new data available nowadays, it seems appropriate to obtain new estimates to yield results on this matter for a longer and particularly turbulent period of time.

This paper is organized as follows. In Section 2, we undertake a brief literature review on the relationship between wealth and consumption and the recent evidence using macro- and micro-data. In Section 3, we analyze the techniques available to estimate the wealth distribution and justify the selection of the EFF to perform our estimation; we also comment the main characteristics of this data source and how it defines our variables of interest. In Section 4, we present a descriptive analysis regarding wealth and consumption to examine the changes that have occurred in the way these variables are distributed in the period studied. In Section 5, we explain the econometric techniques used for the estimation and present the model. In Section 6, we show the main results derived from the econometric analysis and their implications. Finally, Section 7 summarizes the conclusions of our paper.

\section{Literature review}

There is a vast amount of literature on the link between personal wealth and consumption, starting with the seminal work of Modigliani, Ando and Brumberg and their life-cycle hypothesis (Modigliani and Brumberg, 1954, 1979; Ando and Modigliani, 1963).

The life-cycle hypothesis (LCH) posits that individuals plan their consumption and savings over their life-cycle with the intention of optimizing their consumption throughout their lives. To achieve this, they accumulate wealth during their working years and make use of it after their retirement. Assuming this rational planning behavior is widespread, LCH implies that there is a short-term linear relationship between consumption and income and wealth.

Since then, the flow of economic literature on this issue has been relentless (Sousa, 2009). And in recent years, this issue has been extensively addressed making cross-country comparisons such as the following. 
Barrell and Davis (2007) estimated the impact of financial liberalization on consumption in seven OECD countries to find a significant behavioral change, involving a drop in shortrun income elasticities and an increase in short-run wealth.

Slacalek (2009) investigated the effect of wealth on consumption in a data set with financial and housing wealth from 16 countries. Among the author's findings are the strong relationship between consumption and wealth in countries with developed mortgage markets, the greater effect of financial wealth on consumption compared to real wealth and the substantial increase in housing wealth because of the ease of access to credit experienced in recent decades.

In turn, Sousa (2009) estimates wealth in the euro area as a whole. In addition to being statistically significant, the author points out that the housing wealth effect is practically nil, while in the long term, consumption is very responsive to changes in financial wealth.

Barrell et al. (2015) compare the estimated wealth effects of Italy and the UK for a period that includes the Great Recession. While in both countries the changes in wealth are significant to explain changes in consumption, the effect of the components is considerably different for these two countries: housing wealth is increasingly important in the UK, but the opposite is the case in Italy, where financial wealth is increasingly important.

Among the articles that, just like ourselves, make estimates for a single country using survey micro-data, we find Lehnert (2004), who estimated the consumption elasticity of house price changes in the USA by age quintiles and found that they were generally significant, albeit with considerable differences between these groups; Grant and Peltonen (2005), who estimated the housing and financial wealth effects for Italian households and found both to be quite significant but with varying degrees of intensity; Bostic et al. (2009), who found relatively large wealth effects for American households; and Browning et al. (2013), who estimated housing wealth effects for Denmark and found little evidence of it.

As several of the previous studies point out, households' consumption behavior could be affected not only by the value of their wealth stock but also by its composition, that is, the types of assets they hold and their liquidity. Among the transmission channels that share real and financial wealth, we find the realized wealth effect - if asset prices rise and households sell them, then they would be able to boost consumption - the unrealized wealth effect - even if they do not sell the assets, households discount the increase in price and may consume more - and the liquidity constraints effect - an increase in asset prices reduces the credit constraints of households by increasing the value of what they can offer as collateral for a loan (Ludwig and Sløk, 2002).

Nevertheless, the marginal propensity to consume of both real and financial wealth may differ for several reasons. On the one hand, sometimes increases in households' wealth may be perceived as uncertain or temporary, so they will have a different impact on consumption. On the other hand, there may be fiscal incentives to prevent certain types of assets from being used to finance current expenses. In addition, the accumulation of some specific assets may be perceived as a means - for example, to secure housing - whereas the accumulation of others may be considered as an end in itself. Furthermore, the precision with which capital gains can be measured is also important and varies greatly depending on the type of asset: while changes in financial asset prices can be retrieved instantly at any time, this is not the case for housing prices, as their relative illiquidity make their capital gains more inaccurate and uncertain. Finally, there are psychological reasons that may lead households to perceive some assets as short term and cashable and others as long-term investments (Ludwig and Sløk, 2003; Case et al., 2005).

In the light of all these considerations and to the best of our knowledge, there is only one major study that estimates the wealth effect for the Spanish economy by the means of micro- 
AEA 28,83

data (Bover, 2005). In this paper, elasticities are estimated using EFF data to assess the effects of several wealth categories on consumption. Her results suggest that the marginal propensity to consume of housing wealth is equal to 0.015 . Nonetheless, it must be taken into account that the author relies exclusively on data from the first wave of the survey, as it was the only one available at the time.

Conversely, another recent study (Anghel et al., 2018) examines exhaustively the evolution of income, wealth and consumption inequality in Spain using, among other sources, EFF data. However, the authors do not discuss the connection between the changes in wealth and consumption inequality, which leaves the door open for a more in-depth analysis.

Therefore, the contribution of this article is threefold: first, an estimation of the relationship between wealth and consumption in Spain using micro-data, a technique that has been relatively unexplored until now; also, the disaggregation of the effects of real and financial wealth to dig deeper into the link between wealth and consumption over a period of major economic changes; and, finally, through a quantile regression, an analysis of how the previous estimates might change depending on the position of a household in the distribution.

\section{Data sources and definition of variables}

\subsection{Assessment and selection of the data source}

The data source is one of the first issues to be addressed when doing research work on the effect of household wealth on consumption. The measurement of both wealth variables is imprecise and is deeply affected by the data source.

However, while only household surveys are available to estimate the consumption distribution, wealth can be measured using a variety of techniques. Davies and Shorrocks (2000) point out four possible methods for estimating the wealth distribution: household surveys of assets and liabilities, wealth and estate tax records, estate multiplier estimates and investment income data.

Surveys that collect information on assets and liabilities held by households can be used to determine how income is distributed in a population. However, it should be noted that, given the skewness of wealth distribution, the estimates will be necessarily affected by sample error regardless of their size. Besides, the non-sampling errors are also relevant: the non-response rate, either for the entire survey or for a particular question, is higher in the case of the most affluent households, and the misreporting of both assets and debts may have a significant impact on the quality of the results.

Although in Spain there is a tax on personal wealth (Impuesto sobre el Patrimonio), there are several important aspects that make it unsuitable to estimate the wealth distribution on the basis of tax data: its high non-taxable minimum (between $€ 400,000$ and $€ 700,000$ ), the considerable regional differences caused by the transfer of this tax to the autonomous communities, the high levels of tax avoidance (particularly for the wealthiest individuals) and the fact that some assets, such as durable consumer goods, are missing, while others such as land - are severely undervalued, all of which make this data source incomplete and inaccurate.

Moreover, regarding the estate tax records (Impuesto de Sucesiones y Donaciones), in addition to problems similar to those above-mentioned for property tax (i.e. high non-taxable minimum, regional differences, data inaccuracy, etc.), the non-random nature of mortality in terms of age, gender or income level imply we cannot consider any sample of taxpayers representative of the total population. Consequently, the methodological complications of 
using estate multiplier techniques and the relatively poor quality of the results obtained render it an impractical way of estimating the wealth distribution.

Finally, the investment income method (also known as capitalization method) estimates the value of the assets held by an individual using the income from those assets reported in their income tax return. However, the existence of assets that do not generate income flows to their holder (such as the main residence, a secondary non-rented dwelling, works of art, etc.) and the inherent difficulty of estimating the value of any asset from the income it generates make us discard this method to make an estimate of the wealth distribution in Spain.

Considering all of the above and the goals of our research, we opted to use a household survey to estimate the wealth and consumption distribution. To do so, we the EFF provides a representative sample using stratification techniques and oversampling by wealth, ensuring the inclusion of both a sufficient number of households with a large net worth and a wide variety of assets. In addition, the EFF includes a series of socio-demographic variables (household size, educational level, age, employment status, gender, marital status, etc.) that will allow us to enrich the analysis.

Starting from the data included in each wave of the EFF (from 2002 to 2014), we could construct a panel data set that would let us track a group of households for a maximum of four waves because of the rotating nature of the panel. However, this would mean such a large-scale loss of observations (households that are not included in all waves) that the sample would not be representative, and therefore, we could not make inferences with regard to the population.

Thus, to preserve the possibilities offered by these samples, we have decided to take an approach that will allow us to minimize these problems while still being able to exploit the longitudinal nature of the data.

When first conducting our estimations, we will work with cross-sectional data from each of the EFF waves separately and then complete these results with those from two-wave panels. This dual strategy will allow us to track changes in estimated elasticities over time using a representative sample while controlling for potential endogeneity problems associated with wealth variables.

Finally, it must be noted that there may be some differences among the results obtained using EFF data and those derived from other sources such as the World Inequality Database (WID), because, for instance, the EFF refers to households, whereas the WID refers to individuals, and what is more, while the EFF calculates variables from household survey data, the WID uses secondary data sources (published papers).

\subsection{Definition of variables}

All the variables that will be used here are defined according to the Bank of Spain criteria in the preparation of the EFF.

Thus, total household income is defined as the sum of the pre-tax income of all household members. In the cases of missing data for any of these components, a direct imputation of this total income was carried out (Bover, 2004).

Gross household wealth is equal to the sum of the values of the real and financial assets of all members of the household; by subtracting from this sum the total debt of these members, we obtain the net wealth. Although it is reasonable to assume that consumption patterns are essentially driven by each household's available income net of income taxes than by its gross income, we have been forced to use this variable to proxy household income because of the unavailability of data regarding the amounts paid in taxes by household unit.

Total household consumption is defined as the sum of expenditure on non-durable (food, electricity, water, gas, landline and mobile phone, internet connection, subscriptions to cable 
AEA 28,83

\section{8}

or satellite, community fees, leisure, school/university, travel, etc.) and durable (vehicles, furniture, home electrical appliances, curtains, rugs, etc.) consumption.

With regard to the sociodemographic variables of households, we will use the status of the main residence (mortgaged ownership, debt-free ownership or other), number of household members (from one to five or more), number of adult household members working (from none to three or more) and the following data of the household head: age (1634, 35-44, 45-54, 55-64, 65-74, 75 or older), working status (employee, self-employed, retired, other type of economic inactivity or unemployed), educational level (primary, secondary or university education), gender and marital status [single, married, domestic partnership, separated, divorced or widow(er)].

To take into account the changes in purchasing power over time, all the amounts of monetary variables have been converted to 2014 euros using the factors provided by the Bank of Spain.

\section{Descriptive analysis}

Before starting to make estimates about the relationship between wealth and consumption, we will discuss several key empirical facts drawn from the successive waves of the EFF considering that all the measures and figures in this article are calculated using the weight assigned by the survey to each household.

In Figure 1, we can take a first look at the evolution of the Gini indices for wealth and consumption.

The increase in wealth inequality - both gross and net - was matched by a drop in consumption inequality. These diverging trends would serve to catch a first glimpse of the changes in the relationship between wealth and consumption during the period analyzed here.

To delve deeper into the changes in the Gini indices of wealth and consumption, we can split the wealth distribution into groups. This way, in Figure 2, we can see a scenario with very clear trends: households at the top of the distribution increased their share of net wealth, while the middle and lower classes generally experienced a reduction. In addition, this decline in the share of total wealth is greater as we move downward in distribution, to such an extent that households in the first quintile registered negative net wealth for the first time in 2014.

Figure 1.

Gini indices for gross and net wealth and consumption, 20022014

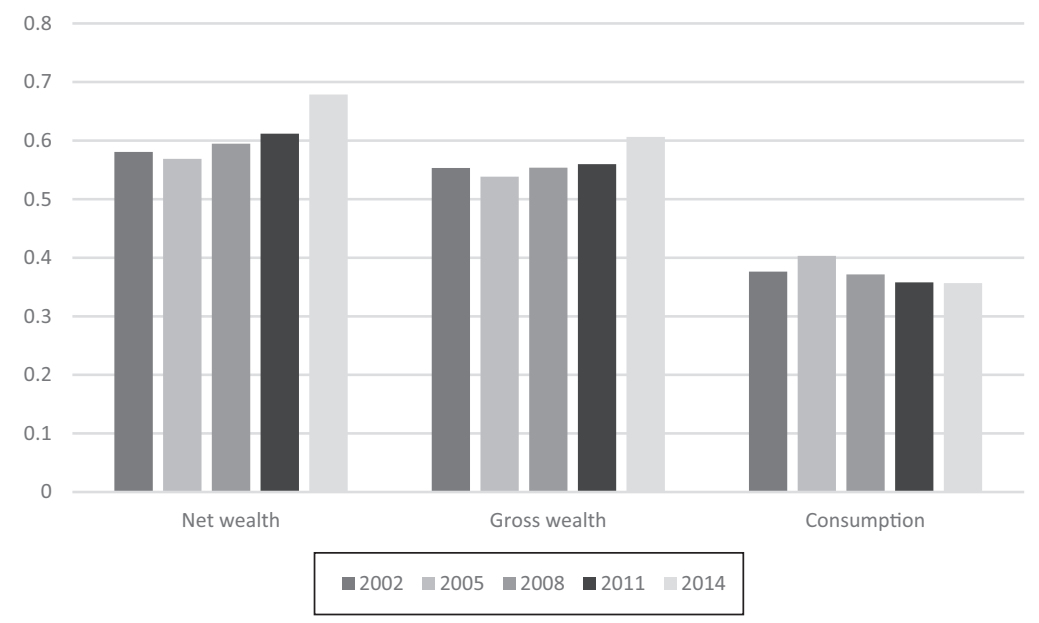




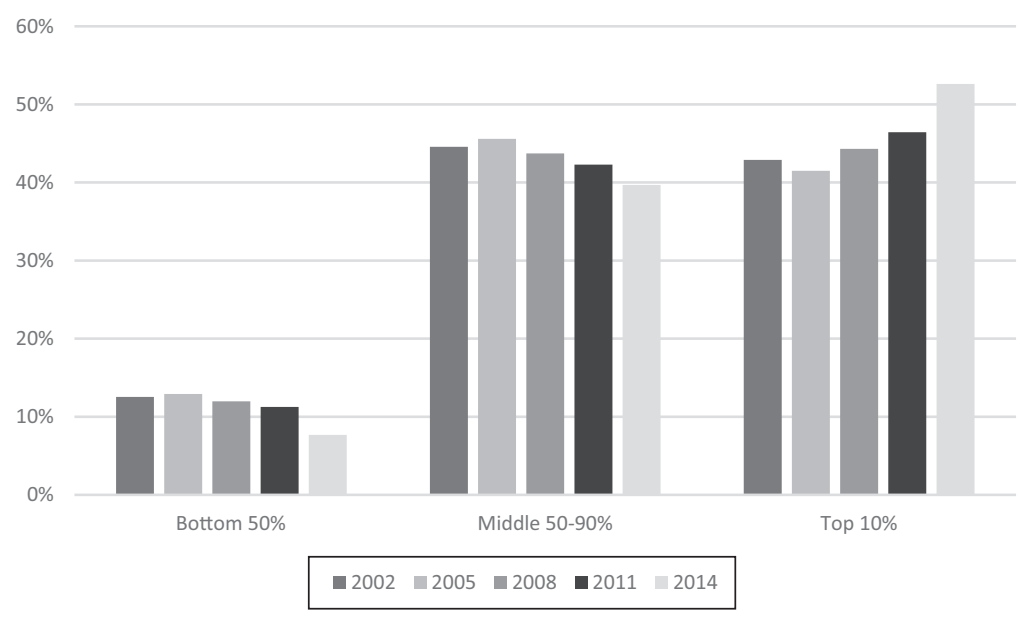
Wealth and consumption inequality

In terms of composition, real wealth is by far the most important way Spanish households have to preserve their wealth. Nevertheless, starting from the third wave of the EFF, which coincided with the onset of the last economic crisis, financial wealth has become increasingly important for the middle class and, especially, for better-off households (Figure 3).

Keeping the same breakdown by net wealth quintiles, we can analyze how consumption behaved to determine the potential cause for the fall in consumption inequality observed in the Gini index (for more details of the demographic characteristics of households by net wealth quintiles, see Appendix).

Although there was a general drop in consumption between the first and last waves, it was noticeably more significant for households at the bottom half of the distribution. As a result, given their relatively smaller consumption drop, households in the middle

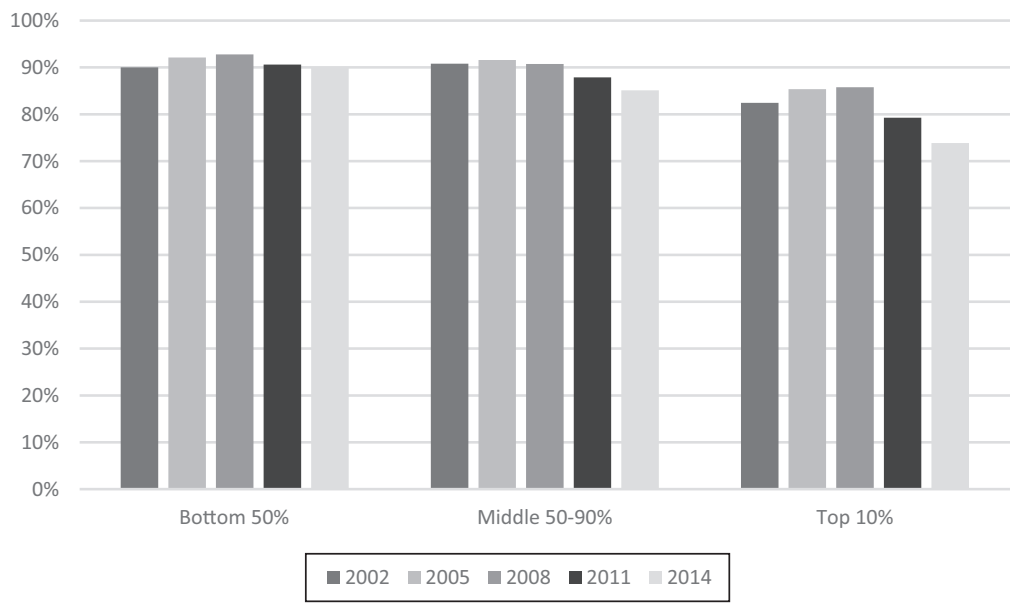

Figure 3.

Proportion of household wealth held in real assets by net wealth groups, 2002-2014
Net wealth shares by groups, 2002-2014 


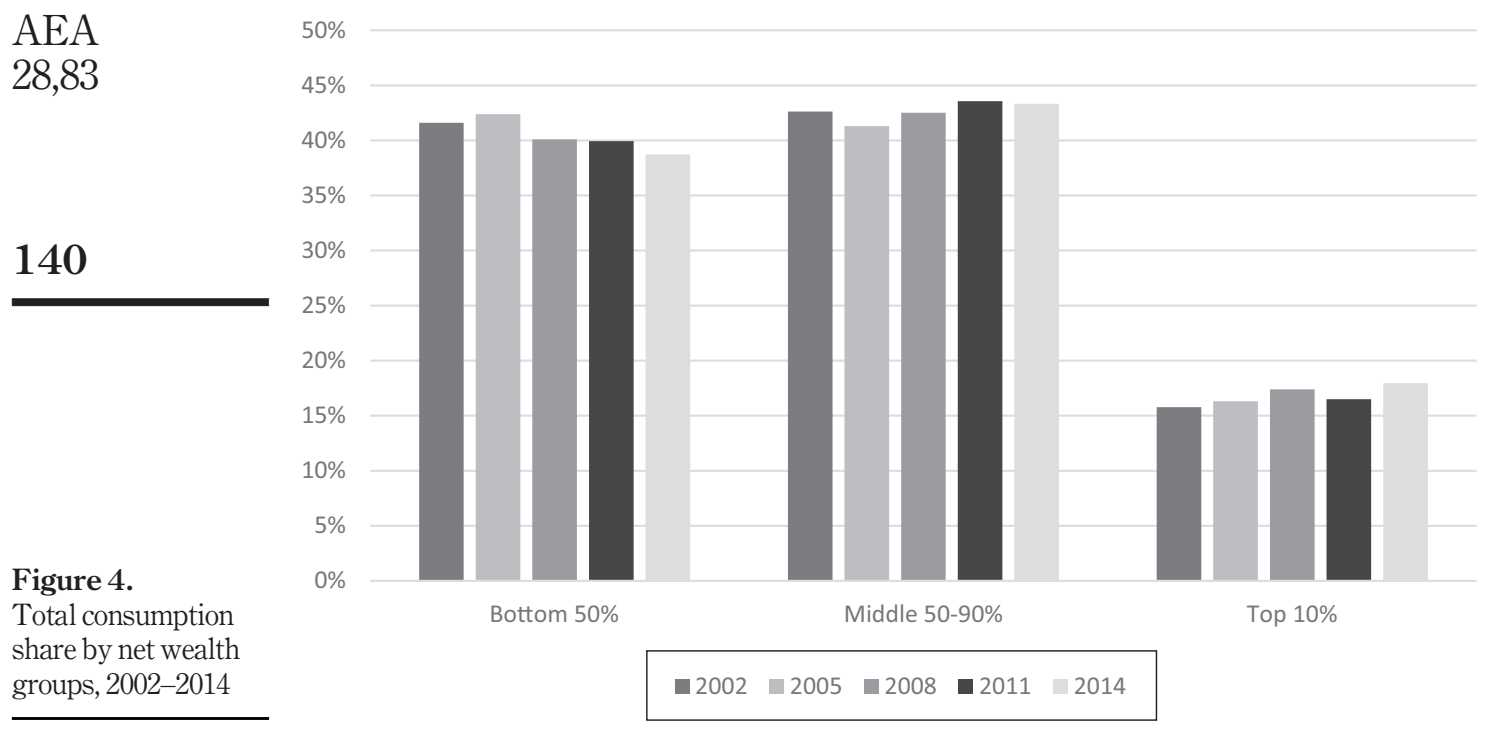

class and at the top of the wealth distribution increased their share in total consumption (Figure 4).

This sharper fall in consumption for lower class households can be related to the fact that the increasing risk of unemployment that arises during crises compels low-income households to reduce their consumption expenditure, as they were unable to save money enough to smooth fluctuations in consumption (Amromin et al., 2017).

The recomposition of consumption that took place during the years under analysis can also be noticed in the type of households' consumption depending on their wealth. According to the definitions of durable and non-durable consumption given in the previous section, there were several notable changes.

First, there was a common trend for all households whereby the proportion of durable consumption in total consumption peaked during the pre-crisis years and then fell steadily with each subsequent wave of the survey. Also, as depicted in Figure 5, the magnitude of the collapse in durable consumption was almost the same for all households, regardless of their level of wealth. In short, households are spending less and less on durable goods, both in absolute terms and as a proportion of total consumption.

\section{Methodology}

To explain the relationship between consumption and wealth, we could start with a simple $\log$ linear function where wealth is the explanatory variable of interest, and household income and a set of socio-demographic variables are included as control variables.

Therefore, a first function would be as follows:

$$
\log (\operatorname{consump})=f[\log (\text { income }), \log (\text { netwealth }), V]
$$

where consump stands for the sum of expenditure on durable and non-durable goods, income the total income of the household, netwealth its net wealth and $V$ is the set of sociodemographic variables (included as dummies) explained in Section 3. 


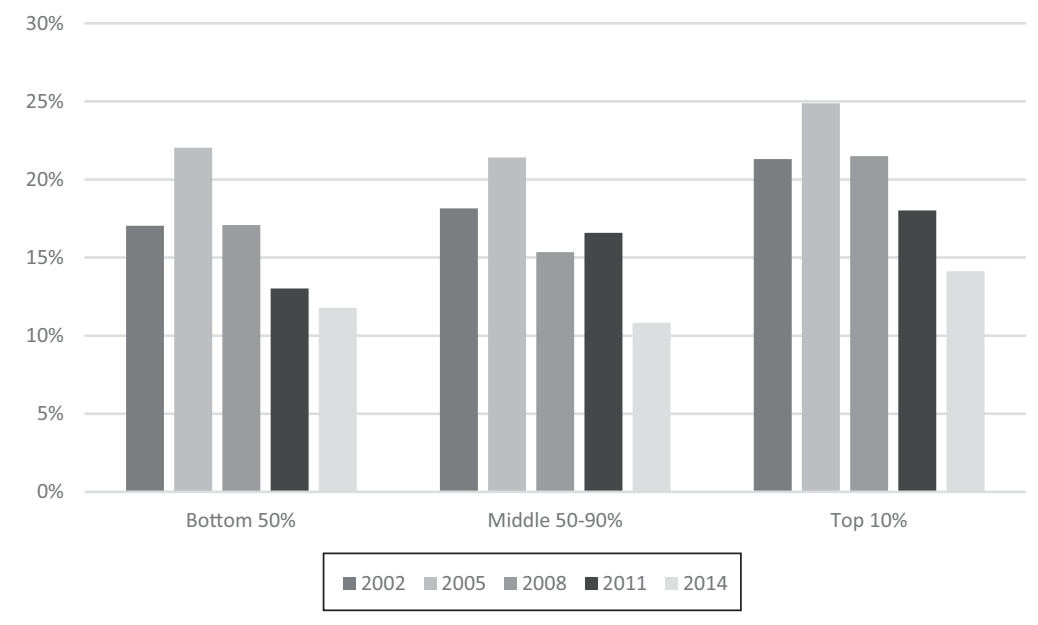

Figure 5.

Proportion of

household

consumption of durable goods by net wealth groups, 2002-

Although some of the sociodemographic variables could have been included as continuous variables in the model, they were incorporated as dummies to take into account possible non-linear relationships with the explained variable (Lynch, 2003). Also, considering that net wealth can take negative values, which causes problems for its transformation into logarithms, it is convenient to disaggregate it into gross wealth (grwealth) and total debt stock (penddebt). The former function will now convert into this one:

$$
\log (\text { consump })=f[\log (\text { income }), \log (\text { grwealth }), \log (\text { penddebt }), V]
$$

To capture the possible disparate effects of real and financial wealth on household consumption, we decided to change equation (2) to include them separately.

Furthermore, considering the crucial importance of housing wealth for Spanish households and the fluctuations experienced by the real estate market during the period analyzed, it seems that this variable might be closely related to household consumption decisions. For this reason, we decided to also separate the value of the main residence (owned for around $80 \%$ of households) (mainresid) and the rest of the real assets (restrealwealth), which may have a lower value or be owned by a smaller percentage of households. Therefore, equation (2) transforms into:

$$
\begin{aligned}
\log (\text { consump })= & \beta_{0}+\beta_{1} \log (\text { income })+\beta_{2} \log (\text { mainresid })+\beta_{3} \log (\text { restrealwealth }) \\
& +\beta_{4} \log (\text { finwealth })+\beta_{5} \log (\text { penddebt })+V+e_{i t}
\end{aligned}
$$

where finwealth stands for 'financial wealth.'

To make the estimation of model of equation (3), we decided to use a robust (i.e. heteroscedasticity-corrected) OLS model for each cross-section. Also, we performed interquantile regressions to obtain a more comprehensive picture of the relationship between wealth and consumption.

Quantile regression methods are used to model the relationship among a series of independent variables and specific percentiles of the dependent variable. Thus, whereas in a traditional linear regression the coefficients represent the increase in the dependent variable 
AEA

28,83

\section{2}

produced by an increase in the corresponding independent variable, the quantile regression coefficient estimates the change in a specific quantile of the explained variable produced by a change in the corresponding regressor (Koenker and Hallock, 2001).

Quantile regression allows comparing how the dependent variable might be more or less affected by each explanatory variable depending on the specific percentile of the dependent variable we want to focus on. This feature is particularly useful considering that it is not unreasonable to think that the relationship between wealth and consumption might change significantly depending on the relative position of a household in the distribution.

Therefore, another key advantage of this methodology over OLS estimations is its robustness in the presence of non-normal errors and outliers in the variable under analysis. This feature provides a deeper understanding of the data and gives the researcher the possibility to account for the impact of a certain regressor in the distribution of the dependent variable and not just its mean.

Moreover, regarding the features of the database, the following section presents estimation results for cross-sections and for two-wave panels. In the first group of estimates, OLS and interquartile estimates will be used, as mentioned above, while in the second, we will apply random-effects panel estimation methods.

For all cases, as the Bank of Spain makes five imputations to correct item non-response, all the estimates are obtained using regression methods adapted to the structure of the database. Furthermore, each household is assigned a cross-sectional weight to compensate for unequal probability of the household being selected into the sample given the oversampling of the wealthy in the EFF and geographical stratification and differential unit non-response.

\section{Results}

\subsection{Cross-section results}

Table I shows the estimated results of equation (3) for each cross-section, once corrected for some heteroscedasticity problems by means of a robust OLS estimator. The sociodemographic variables are included in all estimations although not shown in the table.

The results reveal that all wealth variables are generally significant to explain changes in consumption and that, although in all cases they share a positive sign, their influence on the explained variable has different magnitude.

The relationship between consumption and the value of the main residence resembles the behavior of house prices in Spain explained in the Introduction: the elasticity with respect to consumption expenditure grew by $70 \%$ between 2002 and 2008 and plummeted during the following two waves, returning to a level very close to the estimate of the first wave.

\begin{tabular}{lllllll}
\hline & & 2002 & 2005 & 2008 & 2011 & 2014 \\
\hline OLS estimation & Income & $0.1143^{* * * *}$ & 0.0288 & $0.1060^{* * * *}$ & $0.1201^{* * *}$ & $0.1922^{* * * *}$ \\
& Main residence & $0.1055^{* * *}$ & $0.1187^{* * * *}$ & $0.1698^{* * *}$ & $0.1141^{* * *}$ & $0.1022^{* * * *}$ \\
& Other real wealth & 0.0030 & $0.0089^{* * *}$ & $0.0084^{* * *}$ & $0.0089^{* * *}$ & $0.0052^{* * *}$ \\
& Financial wealth & $0.0449^{* * *}$ & $0.0378^{* * *}$ & $0.0179^{* * *}$ & $0.0253^{* * *}$ & $0.0292^{* * *}$ \\
& Outstanding debt & $0.0212^{* * *}$ & $0.0288^{* * *}$ & $0.0106^{* * *}$ & 0.0014 & $0.0099^{* * *}$ \\
& Observations & 5,143 & 5,962 & 6,197 & 6,085 & 6,117 \\
& $R^{2}$ & 0.4550 & 0.4345 & 0.4865 & 0.4758 & 0.5292
\end{tabular}

Table I.

Total consumption robust OLS estimates, 2002-2014
Notes: ***; **; and * indicate rejection of the null hypothesis at the 1, 5 and $10 \%$ significance levels, respectively 
On the other hand, the remaining real assets in the hands of households (second dwellings, stores and offices, industrial warehouses, land, plots, etc.) have a significant and stable connection with consumption, although of residual importance - in all cases, a $1 \%$ change in the value of these assets would result in a change of less than $0.01 \%$ in household consumption.

Financial assets have far smaller estimated coefficients than the value of the main residence. As can be seen in Table I, the evolution of the estimated coefficients reflects a behavior opposite to the main category of real assets, with a decline in the estimated elasticities until 2008 and an increase thereafter.

As regards the control variables, the estimated elasticity of consumer spending relative to household income and outstanding debt are generally significant and positive. Nevertheless, during the period under analysis, there are large variations in the estimated effects that a change in these two variables may have on consumption: for instance, in 2005, income is not significant to explain changes in consumption, and since then, the sensitivity of consumption to alterations in income increases with each successive wave of the EFF; in turn, the magnitude of the effect the outstanding household debt has on consumption is relatively limited and decreasing in relevance over time.

Finally, the dummy variables, also included in the model as control variables to improve the goodness of the fit and to isolate the effect of our variables of interest, are jointly significant in all cases.

To analyze how these estimates vary throughout the distribution, we present in Table II the estimates of equation (3) for each cross-section using interquantile regression techniques for the 10th, 25th, 50th, 75th, 90th and 99th percentiles (To help visualize the data, we have included in Annex 1 graphical representations of Table II).

The estimated elasticities of the value of the main residence for the different positions in the consumption distribution follow a pattern similar to that described for the results in Table I, with an increase during the years of economic growth and a subsequent downturn after the onset of the crisis. At the same time, in each consumption group and for each crosssection, the estimated elasticity of this type of asset grows dramatically as we approach the top end of the distribution.

Nonetheless, the scale of these changes is significantly different across groups: the central groups of the distribution are the ones that increased most the estimated elasticity of the main residence on consumption during the critical years of the Spanish housing bubble. However, after its collapse, the subsequent decline was felt most strongly in households at the lower end of the distribution, which resulted in reductions in the estimated coefficients that led them well below those at the beginning of the period.

These results could be useful to explain the drop in consumption share that households at the bottom 50\% experienced during the crisis. These households are increasingly dependent on their income and less on their wealth to determine their consumption preferences, which, together with the loss of income resulting from the crisis - these households are more affected by unemployment and lower wages - could cause a proportionally more severe drop in their consumption than in the case of the remaining households.

In relation to the rest of the real wealth, there is a similar pattern of rise and fall in the estimated coefficients for all households except those placed in the tails of the distribution. Nonetheless, the value of these coefficients suggests that the influence that this type of assets may have on consumption is generally testimonial. Notwithstanding, it is important to note that for households at the very top, the coefficients can take values higher than 0.01 . 


\section{AEA 28,83}

\begin{tabular}{|c|c|c|c|c|c|c|}
\hline & & 2002 & 2005 & 2008 & 2011 & 2014 \\
\hline \multirow[t]{7}{*}{ 10th percentile } & Income & $0.1868^{* * *}$ & $0.1242^{* * *}$ & $0.2029^{* * * *}$ & $0.2494^{* * * *}$ & $0.3616^{* * * *}$ \\
\hline & Main residence & $0.0868^{* * * *}$ & $0.0642^{* * *}$ & $0.1184^{* * * *}$ & $0.0712^{* * *}$ & $0.0300 * * *$ \\
\hline & Other real wealth & $0.0045^{* *}$ & $0.0027 * * *$ & $0.0040^{* * * *}$ & $0.0087 * * *$ & $0.0052^{* * * *}$ \\
\hline & Financial wealth & $0.0338 * * *$ & $0.0273^{* * * *}$ & $0.0193 * * *$ & $0.0149^{* * *}$ & $0.0212^{* * * *}$ \\
\hline & Outstanding debt & 0.0119 **** & $0.0206^{* * * *}$ & -0.0006 & $-0.0084 * * *$ & 0.0014 \\
\hline & Observations & 5,143 & 5,962 & 6,197 & 6,085 & 6,117 \\
\hline & $R^{2}$ & 0.4308 & 0.3857 & 0.4430 & 0.4180 & 0.4718 \\
\hline \multirow[t]{7}{*}{ 25th percentile } & Income & $0.1852^{* * * *}$ & $0.0790^{* * * *}$ & $0.1712^{* * * *}$ & 0.2436 *** & $0.3295^{* * * *}$ \\
\hline & Main residence & $0.0803^{* * * *}$ & $0.1215^{* * *}$ & 0.1757 *** & $0.0572^{* * * *}$ & $0.0638 * * *$ \\
\hline & Other real wealth & $0.0039 * *$ & $0.0068^{* * * *}$ & $0.0044^{* * * *}$ & $0.0056^{* * * *}$ & $0.0040^{* * * *}$ \\
\hline & Financial wealth & $0.0408^{* * * *}$ & $0.0330^{* * * *}$ & $0.0161^{* * * *}$ & $0.0156^{* * * *}$ & $0.0173^{* * * *}$ \\
\hline & Outstanding debt & $0.0138^{* * * *}$ & $0.0222^{* * *}$ & $0.0035^{\text {**** }}$ & $-0.0047 * * *$ & $0.0064 * * *$ \\
\hline & Observations & 5,143 & 5,962 & 6,197 & 6,085 & 6,117 \\
\hline & $R^{2}$ & 0.4411 & 0.4160 & 0.4684 & 0.4369 & 0.4962 \\
\hline \multirow[t]{7}{*}{ 50th percentile } & Income & $0.1533^{* * * *}$ & $0.0378^{* * * *}$ & $0.1222^{* * * *}$ & $0.1934^{* * * *}$ & $0.3325^{* * * *}$ \\
\hline & Main residence & $0.0920 * * *$ & $0.1216^{* * *}$ & $0.1959 * * *$ & $0.0889 * * *$ & $0.0685^{* * * *}$ \\
\hline & Other real wealth & $0.0052^{* * *}$ & $0.0077^{* * * *}$ & $0.0077^{* * * *}$ & $0.0063^{* * *}$ & $0.0034^{* * * *}$ \\
\hline & Financial wealth & $0.0328 * * *$ & $0.0365^{* * * *}$ & $0.0176^{* * * *}$ & $0.0194 * * *$ & $0.0155^{* * * *}$ \\
\hline & Outstanding debt & $0.0190 * * *$ & $0.0300^{* * * *}$ & $0.0065^{* * * *}$ & $0.0019 * * *$ & $0.0076^{* * * *}$ \\
\hline & Observations & 5,143 & 5,962 & 6,197 & 6,085 & 6,117 \\
\hline & $R^{2}$ & 0.4506 & 0.4334 & 0.4857 & 0.4606 & 0.5011 \\
\hline \multirow[t]{7}{*}{ 75th percentile } & Income & 0.1197 *** & $0.0388^{* * * *}$ & 0.1069 *** & $0.1325^{* * *}$ & $0.2314 * * *$ \\
\hline & Main residence & $0.1035^{* * * *}$ & $0.1509 * * *$ & $0.1690^{* * * *}$ & $0.1109 * * *$ & $0.0895^{* * * *}$ \\
\hline & Other real wealth & $0.0024^{* * * *}$ & $0.0097 * * *$ & $0.0098^{* * * *}$ & $0.0041 * * *$ & $0.0041^{* * * *}$ \\
\hline & Financial wealth & $0.0345^{\text {**** }}$ & $0.0331 * * *$ & $0.0118^{* * * *}$ & $0.0263^{* * *}$ & $0.0222^{* * * *}$ \\
\hline & Outstanding debt & $0.0298^{* * * *}$ & $0.0348^{* * * *}$ & $0.0181^{* * * *}$ & $0.0070^{* * * *}$ & $0.0147^{* * * *}$ \\
\hline & Observations & 5,143 & 5,962 & 6,197 & 6,085 & 6,117 \\
\hline & $R^{2}$ & 0.4483 & 0.4235 & 0.4768 & 0.4681 & 0.5202 \\
\hline \multirow[t]{7}{*}{ 90th percentile } & Income & $0.0846^{* * * *}$ & $0.0329 * * *$ & $0.0829 * * *$ & $0.0924 * * *$ & $0.1250 * * *$ \\
\hline & Main residence & $0.1161^{* * *}$ & $0.1357^{* * * *}$ & $0.2014^{* * * *}$ & $0.1173^{* * *}$ & $0.1048^{* * * *}$ \\
\hline & Other real wealth & $0.0003^{* * * *}$ & $0.0107 * * *$ & $0.0130 * * *$ & $0.0111 * * *$ & $0.0064 * * *$ \\
\hline & Financial wealth & $0.0506^{\text {**** }}$ & $0.0331^{* * * *}$ & $0.0132^{* * * *}$ & $0.0312^{* * *}$ & $0.0356^{* * * *}$ \\
\hline & Outstanding debt & $0.0256^{* * * *}$ & $0.0354 * * *$ & $0.0226^{* * * *}$ & $0.0170 * * *$ & $0.0172^{* * * *}$ \\
\hline & Observations & 5,143 & 5,962 & 6,197 & 6,085 & 6,117 \\
\hline & $R^{2}$ & 0.4290 & 0.4032 & 0.4587 & 0.4416 & 0.5021 \\
\hline \multirow[t]{7}{*}{ 99th percentile } & Income & $0.0685^{* * * *}$ & $0.0019 * * *$ & $0.0901^{* * * *}$ & $0.0497 * * *$ & $0.0850 * * *$ \\
\hline & Main residence & $0.1646^{* * * *}$ & $0.1264^{* * * *}$ & $0.1808^{* * * *}$ & $0.0983^{* * * *}$ & $0.2276^{* * * *}$ \\
\hline & Other real wealth & -0.0024 & $0.0300^{* * * *}$ & $0.0191^{* * * *}$ & $0.0302^{* * *}$ & $0.0088^{* * * *}$ \\
\hline & Financial wealth & $0.0698^{* * * *}$ & $0.0339 * * *$ & $0.0221^{* * * *}$ & $0.0601^{* * * *}$ & $0.0322^{* * * *}$ \\
\hline & Outstanding debt & $0.0232^{* * * *}$ & $0.0392^{* * *}$ & $0.0159 * * *$ & $0.0149 * * *$ & $0.0137 * * *$ \\
\hline & Observations & 5,143 & 5,962 & 6,197 & 6,085 & 6,117 \\
\hline & $R^{2}$ & 0.3366 & 0.3350 & 0.3924 & 0.3137 & 0.4376 \\
\hline
\end{tabular}

Table II.

Total consumption interquantile regression estimates, 2002-2014
Notes: ***; **; and * indicate rejection of the null hypothesis at the 1, 5 and $10 \%$ significance levels, respectively

Finally, wealth held in financial assets - which includes checking accounts, fixed deposit accounts, bonds, shares, etc. - has a significant but much smaller estimated coefficients than the most relevant category of real wealth - the main residence.

The evolution of the estimated coefficients reveals many differentiated behaviors depending on the position of a household in the consumption distribution: almost all households, except those at the very top, experienced a U-shaped trend, which becomes increasingly pronounced as we move upward in the distribution. 
Overall, financial wealth seems to have lost influence on the consumption decisions of Spanish households, while real wealth - and, particularly, main housing - gained ground, probably as a result of the real estate price bubble. This process reversed with the onset of the crisis, although for the last EFF wave the values estimated at the beginning of the period under analysis have not recovered completely yet.

As a final point regarding financial wealth, the differences in the estimated coefficients among households in different positions of the distribution appear to be much smaller than in the case of the two real wealth categories. Thus, a change that equally affects the financial wealth of all Spanish households would produce relatively similar changes in terms of household consumption.

As for the two control variables introduced in the model, several issues need to be addressed. First, we should highlight the increasing influence of household income when explaining consumption behavior, a trend common to all groups. Second, the estimated coefficients of income elasticity on consumption decrease as we move upward in the consumption distribution and diverge steadily with each new survey wave. All this implies that Spanish households - and particularly those at the bottom half of the distribution - are increasingly reliant on their income to determine their consumption preferences.

In turn, the stock of outstanding household debt plays an increasingly irrelevant role in determining consumption expenditure, especially for households at the top of the distribution. For the rest, its relevance seems to have regained somewhat, although taking values well below those registered during the real estate bubble, when credit conditions were notably softer.

\subsection{Two-wave panel results}

As we pointed out in previous sections, the levels of attrition that are present across different waves of EFF prevent the assembly of long-term panels that would allow us to produce representative results by following the same home throughout the years under analysis.

However, as the results of such an analysis could greatly complement those of the crosssections and address potential endogeneity problems, we have decided to put together twowave panels, where the attrition is the lowest possible, and performed the same estimates as in the previous subsection.

In contrast to the previous subsection, each household is assigned a longitudinal weight to be considered when performing the panel estimates.

It must be noted, nevertheless, that attrition between two consecutive waves ranges from $43.27 \%$ to $66.5 \%$.

As seen in Table III, the results of the estimation for the entire population do not diverge greatly from those presented in Table I for the cross-sections, both in the significance of the variables and in the value and variations in the estimated coefficients.

However, this second estimation allows us, if possible, to perceive the long-term trends of the key income and wealth variables more clearly. Although the fluctuations in the estimated coefficients are smoother, as one might expect, the results point unequivocally to an increase in the estimated elasticity of household disposable income over time and to changes in the estimated elasticity of the value of the main residence that mirror the changes in property prices in Spain during the period under analysis.

All other variables, as in the cross-section estimations, are again showing significant estimated elasticities but with much lower values and relatively small changes. However, it is worth noting yet again the steady loss of influence that changes in household debt have in explaining changes in consumption. 
AEA 28,83

\section{6}

The results produced for the interquartile regressions (Table IV) reinforce those presented in Table II for the cross-sections. There is a substantial increase in the estimated elasticity of disposable income, especially for households in the lower and middle segments of distribution.

Simultaneously, changes in the value of the main residence become less relevant in explaining changes in consumption as we move down the consumption distribution, whereas they grow slightly for households in the fourth quartile. Meanwhile, changes in the remaining real wealth are significant to explain the consumption behavior of households in all distribution segments, albeit with estimated elasticities very close to zero.

The importance of financial wealth, while significant, is considerably weaker and more homogeneous, although it is noteworthy that it is increasing for wealthier households. Debt, on the other hand, has very low estimated elasticities in comparison with the rest of the dependent variables, and these elasticities are losing ground over the years for all segments of the distribution.

\section{Concluding remarks}

Our findings suggest that there was an increase in wealth inequality (both gross and net) during the period 2002-2014 and, at the same time, a reduction in consumption inequality. While households at the top of the distribution account for an increasing share of total wealth, the distribution of consumption is less and less unequal. Nevertheless, on closer examination, it is possible to observe that, although the Gini index indicates that consumption is distributed less and less unequally, this is because of the relative rapprochement of the middle class and the top $10 \%$, while the lower classes consume less and less in both absolute and relative terms.

Regarding our estimates, there is a significant positive relationship between wealth and consumer expenditure. Disaggregating by categories, the primary source of real wealth of Spanish households, namely the main residence, has a considerable effect on consumption, with values ranging from 0.1 to 0.17 for the estimate obtained by means of a robust OLS estimator. Its estimated elasticity during the central years of the 2000 s was higher than that of household income. In addition, the changes in the estimated elasticity of the value of the main residence on consumption follow a behavior pattern that seems to mirror the Spanish housing price index - increasing until 2008 and falling thereafter - which could be associated with the prevalence of housing ownership in Spanish families.

By applying the interquartile regression, a similar trend can be seen, although the increases in elasticity are more noticeable in the middle class, whereas the decreases stand out at the bottom $50 \%$. The relative loss of ground from wealth to income, whose elasticity

\begin{tabular}{llllll}
\hline & & $2002-2005$ & $2005-2008$ & $2008-2011$ & $2011-2014$ \\
\hline OLS estimation & Income & 0.0463 & $0.1013^{* * * *}$ & $0.1365^{* * * *}$ & $0.1445^{* * * *}$ \\
& Main residence & $0.1034^{* * * *}$ & $0.1506^{* * *}$ & $0.1305^{* * *}$ & $0.1303^{* * *}$ \\
& Other real wealth & $0.0070^{* *}$ & $0.0064^{* * *}$ & $0.0073^{* * *}$ & $0.0084^{* * *}$ \\
& Financial wealth & $0.0468^{* * *}$ & $0.0295^{* * *}$ & $0.0164^{* * *}$ & $0.0290^{* * *}$ \\
& Outstanding debt & $0.0275^{* * *}$ & $0.0216^{* * *}$ & $0.0064^{* *}$ & $0.0071^{* * *}$ \\
& Observations & 5,160 & 7,930 & 7,422 & 6,120 \\
& $R^{2}$ & 0.4512 & 0.4782 & 0.4732 & 0.5182
\end{tabular}

Total consumption robust OLS estimates for two-wave panels, 2002-2014
Notes: ***; **; and * indicate rejection of the null hypothesis at the 1,5 and $10 \%$ significance levels, respectively 


\begin{tabular}{|c|c|c|c|c|c|c|}
\hline & & 2002-2005 & 2005-2008 & 2008-2011 & 2011-2014 & Wealth and \\
\hline \multirow[t]{7}{*}{$10^{\text {th }}$ percentile } & Income & $0.2094 * * * *$ & $0.1406^{* * * *}$ & $0.2172 * * *$ & $0.2977 * * *$ & \\
\hline & Main residence & $0.0792^{* * * *}$ & $0.1265^{* * *}$ & $0.0881 * * *$ & $0.0596 * * *$ & \\
\hline & Other real wealth & $0.0077^{* * * *}$ & $0.0032 * *$ & $0.0059 * * * *$ & $0.0072^{* * * *}$ & \\
\hline & Financial wealth & $0.0171^{* * * *}$ & $0.0304^{* * * *}$ & 0.0062 & $0.0075^{* * * *}$ & \\
\hline & Outstanding debt & 0.0146 **** & $0.0092 * * *$ & $-0.0045^{* * * *}$ & -0.0002 & \\
\hline & Observations & 5,160 & 7,930 & 7,422 & 6,120 & 147 \\
\hline & $R^{2}$ & 0.3670 & 0.4415 & 0.4380 & 0.4556 & \\
\hline \multirow[t]{7}{*}{ 25th percentile } & Income & $0.1446 * * *$ & $0.1672 * * *$ & $0.2088 * * *$ & $0.2717 * * *$ & \\
\hline & Main residence & $0.1021 * * *$ & $0.1506^{* * * *}$ & $0.1301 * * *$ & $0.0925 * * *$ & \\
\hline & Other real wealth & $0.0056^{* * * *}$ & $0.0016^{* * * *}$ & $0.0037^{* * * *}$ & $0.0050 * * *$ & \\
\hline & Financial wealth & $0.0352 * * * *$ & $0.0260 * * *$ & $0.0100 * * *$ & $0.0133^{* * * *}$ & \\
\hline & Outstanding debt & $0.0175 * * *$ & $0.0151 * * *$ & $-0.0043 * * *$ & $0.0014 * * *$ & \\
\hline & Observations & 5,160 & 7,930 & 7,422 & 6,120 & \\
\hline & $R^{2}$ & 0.4193 & 0.4611 & 0.4508 & 0.4821 & \\
\hline \multirow[t]{7}{*}{$50^{\text {th }}$ percentile } & Income & $0.0951^{* * *}$ & $0.1249^{* * *}$ & $0.1816^{* * *}$ & $0.2822^{* * * *}$ & \\
\hline & Main residence & $0.1198 * * * *$ & $0.1572 * * *$ & $0.1483 * * *$ & $0.1063 * * *$ & \\
\hline & Other real wealth & $0.0065^{* * * *}$ & $0.0052 * * *$ & $0.0053 * * *$ & $0.0042 * * *$ & \\
\hline & Financial wealth & $0.0365^{* * * *}$ & $0.0293^{* * * *}$ & $0.0142 * * *$ & $0.0162 * * *$ & \\
\hline & Outstanding debt & $0.0302 * * *$ & $0.0193 * * *$ & $0.0069 * * *$ & 0.0011 & \\
\hline & Observations & 5,160 & 7,930 & 7,422 & 6,120 & \\
\hline & $R^{2}$ & 0.4439 & 0.4766 & 0.4661 & 0.4822 & \\
\hline \multirow[t]{7}{*}{$75^{\text {th }}$ percentile } & Income & $0.0534 * * *$ & $0.0864 * * *$ & $0.1440 * * *$ & $0.2332 * * *$ & \\
\hline & Main residence & $0.1354^{* * * *}$ & $0.1601^{* * * *}$ & $0.1040 * * *$ & $0.1214 * * *$ & \\
\hline & Other real wealth & $0.0054 * * *$ & $0.0072 * * *$ & $0.0058 * * *$ & $0.0019 * * *$ & \\
\hline & Financial wealth & $0.0378^{* * * *}$ & $0.0263^{* * * *}$ & $0.0136^{* * * *}$ & $0.0224^{* * * *}$ & \\
\hline & Outstanding debt & $0.0369 * * *$ & $0.0277 * * *$ & $0.0123 * * *$ & $0.0088 * * *$ & \\
\hline & Observations & 5,160 & 7,930 & 7,422 & 6,120 & \\
\hline & $R^{2}$ & 0.4412 & 0.4691 & 0.4638 & 0.4964 & \\
\hline \multirow[t]{7}{*}{$90^{\text {th }}$ percentile } & Income & $0.0320^{* * * *}$ & $0.0735^{* * * *}$ & $0.1154 * * *$ & $0.1089 * * *$ & \\
\hline & Main residence & $0.0919 * * *$ & $0.1585^{* * * *}$ & $0.1417 * * *$ & $0.1822 * * *$ & \\
\hline & Other real wealth & 0.0012 & $0.0079 * * *$ & $0.0120 * * *$ & $0.0083 * * *$ & \\
\hline & Financial wealth & $0.0589 * * * *$ & $0.0280 * * *$ & $0.0237 * * *$ & $0.0424 * * *$ & \\
\hline & Outstanding debt & $0.0303^{* * * *}$ & $0.0265 * * *$ & $0.0214 * * *$ & $0.0245^{* * * *}$ & \\
\hline & Observations & 5,160 & 7,930 & 7,422 & 6,120 & \\
\hline & $R^{2}$ & 0.4145 & 0.4481 & 0.4398 & 0.4870 & \\
\hline \multirow[t]{7}{*}{$99^{\text {th }}$ percentile } & Income & 0.0083 & $0.0825 * * *$ & $0.1024 * * *$ & 0.0158 & \\
\hline & Main residence & 0.0527 & $0.1698 * * *$ & $0.0953 * * * *$ & $0.1633^{* * *}$ & \\
\hline & Other real wealth & $0.0067 * * *$ & $0.0152 * * *$ & $0.0268^{* * * *}$ & $0.0351 * * *$ & \\
\hline & Financial wealth & $0.0793 * * *$ & $0.0355^{* * * *}$ & $0.0312^{* * * *}$ & $0.0453^{* * * *}$ & Table IV. \\
\hline & Outstanding debt & $0.0230 * * *$ & $0.0279 * * *$ & $0.0186^{* * * *}$ & $0.0169 * * *$ & Total consumption \\
\hline & Observations & 5,160 & 7,930 & 7,422 & 6,120 & interquantile \\
\hline & & 0.2830 & 0.3453 & 0.2921 & 0.3618 & regression estimates \\
\hline \multicolumn{6}{|c|}{$\begin{array}{l}\text { Notes: } * * * ; * ; \text {; and } * \text { indicate rejection of the null hypothesis at the } 1,5 \text { and } 10 \% \text { significance levels, } \\
\text { respectively }\end{array}$} & $\begin{array}{r}\text { for two-wave panels, } \\
2002-2014\end{array}$ \\
\hline
\end{tabular}

to consumption is higher with each new wave of the survey, means that households in the first half of the distribution plan their consumption almost exclusively on the basis of their declining and unstable income, resulting in lower consumption expenditure.

Meanwhile, the estimated coefficients for the effects of all financial assets in the hands of Spanish households reveal a reverse trend to that observed in the main category of real assets, although they are always much lower in absolute terms. And the effects of the other 
wealth categories (real assets except main residence, checking accounts and other financial assets), although generally significant, seem to have a much weaker impact on the consumption expenditure of Spanish households, never reaching levels above 0.02, even for the most affluent groups.

Ultimately, our study points to an extremely significant connection between the value of the main residence and household spending and a modest one for the remaining real and financial assets and consumption expenditure. Notwithstanding, this becomes weaker as we approach the present day and move downwards in the distribution, losing nowadays practically all relevance in the definition of preferences to household income.

The replication of the cross-section estimates for two-wave panels, where the attrition is as low as possible, backs up the results described above.

Nevertheless, further research is needed using a sample with a constant set of households that would allow the researcher to obtain long-term estimates for the marginal propensities to consume of each category of income, wealth and debt.

\section{References}

Amromin, G., De Nardi, M. and and Schulze, K. (2017), "Household inequality and the consumption response to aggregate real shocks", National Bureau of Economic Research Working Paper no. 24073.

Ando, A. and Modigliani, F. (1963), "The "Life-Cycle" hypothesis of saving: aggregate implications and rests", The American Economic Review, Vol. 53 No. 1, pp. 55-84.

Anghel, B., Basso, H., Bover, O., Casado, J.M., Hospido, L., Izquierdo, M., Kataryniuk, I., Lacuesta, A., Montero, J.A. and Vozmediano, E. (2018), "Income, consumption and wealth inequality in Spain", SERIEs, Vol. 9 No. 4, pp. 351-387.

Barrell, R. and Davis, E. (2007), "Financial liberalisation, consumption and wealth effects in seven OECD countries", Scottish Journal of Political Economy, Vol. 54 No. 2, pp. 254-267.

Barrell, R., Costantini, M. and Meco, I. (2015), "Housing wealth, financial wealth, and consumption: new evidence for Italy and the UK", International Review of Financial Analysis, Vol. 42, pp. 316-323.

Bostic, R., Gabriel, S. and Painter, G. (2009), "Housing wealth, financial wealth, and consumption: new evidence from micro data”, Regional Science and Urban Economics, Vol. 39 No. 1, pp. $79-89$.

Bover, O. (2004), "Encuesta financiera de las familias españolas (EFF): descripción y métodos de la encuesta 2002", Documentos ocasionales-Banco de España, Vol. 9, pp. 9-32.

Bover, O. (2005), "Wealth effects on consumption: microeconometric estimates from the Spanish survey of household finances", Bank of Spain Working Papers, 0522.

Browning, M., Gørtz, M. and Leth-Petersen, S. (2013), "Housing wealth and consumption: a micro panel study", The Economic Journal, Vol. 123 No. 568, pp. 401-428.

Case, K.E., Quigley, J.M. and Shiller, R.J. (2005), “Comparing wealth effects: the stock market versus the housing market", Advances in Macroeconomics, Vol. 5 No. 1, pp. 1-32.

Davies, J.B. and Shorrocks, A.F. (2000), "The distribution of wealth", Handbook of Income Distribution, Vol. 1, pp. 605-675.

Grant, C. and and Peltonen, T. (2005), "Housing and equity wealth effects of Italian household", DNB Working Papers no. 43.

Koenker, R. and Hallock, K.F. (2001), “Quantile regression”, Journal of Economic Perspectives, Vol. 15 No. 4, pp. 143-156.

Lehnert, A. (2004), "Housing, consumption, and credit constraints", Board of Governors of the Federal Reserve System Working Papers, pp. 2004-2063.

Ludwig, A. and and Sløk, T. (2002), "The impact of changes in stock prices and house prices on consumption in OECD countries", IMF Working Papers, n. 2002-1. 
Ludwig, A. and Sløk, T. (2003), "The relationship between stock prices, house prices and consumption in OECD countries", Topics in Macroeconomics, Vol. 4 No. 1, pp. 1114-1114.

Modigliani, F. and Brumberg, R. (1954), "Utility analysis and the consumption function: an interpretation of Cross-Section data", in Kurihara, K. (Ed.), Post Keynesian Economics, Rutgers University Press, New Brunswick, NJ, pp. 388-436.

Modigliani, F. and Brumberg, R. (1979), "Utility analysis and aggregate consumption functions: an attempt at integration”, in Abel, A. (Ed.), The Collected Papers of Franco Modigliani, Vol. 2, MIT Press, Cambridge, MA, pp. 128-197.

Lynch, S. (2003), "Expanding the model capabilities: dummy variables, interactions, and nonlinear transformations", Princeton University website, www.princeton.edu/ slynch/expanding_ols. pdf

Slacalek, J. (2009), "What drives personal consumption? The role of housing and financial wealth", The BE Journal of Macroeconomics, Vol. 9 No. 1, pp. 1-35.

Sousa, R. (2009), “Wealth effects on consumption: evidence from the euro area”, European Central Bank Working Papers no. 1050. 
AEA

Appendix 1

28,83

150

\begin{tabular}{|c|c|c|c|c|}
\hline & Average age & $\begin{array}{c}\% \text { below secondary education } \\
(\%)\end{array}$ & $\begin{array}{l}\% \text { secondary } \\
\text { education } \\
(\%)\end{array}$ & $\begin{array}{l}\% \text { university } \\
\text { education } \\
(\%)\end{array}$ \\
\hline $\begin{array}{l}\text { Q1\% } \\
\text { share }\end{array}$ & 45.21 & 63.36 & 25.52 & 11.13 \\
\hline $\begin{array}{l}\text { Q2\% } \\
\text { share }\end{array}$ & 53.26 & 64.22 & 20.35 & 15.43 \\
\hline $\begin{array}{l}\text { Q3\% } \\
\text { share }\end{array}$ & 56.70 & 66.68 & 18.60 & 14.72 \\
\hline $\begin{array}{l}\text { Q4\% } \\
\text { share }\end{array}$ & 57.77 & 51.60 & 26.27 & 22.12 \\
\hline $\begin{array}{l}\text { Q5\% } \\
\text { share }\end{array}$ & 59.67 & 33.60 & 23.56 & 42.85 \\
\hline $\begin{array}{l}\text { Q1\% } \\
\text { share }\end{array}$ & $\begin{array}{l}\text { \% Employee } \\
\quad 48.66\end{array}$ & $\begin{array}{c}\text { \% Self-employed } \\
4.19\end{array}$ & $\begin{array}{l}\text { \% Retired } \\
\quad 9.82\end{array}$ & $\begin{array}{c}\text { \% Unemployed } \\
37.33\end{array}$ \\
\hline $\begin{array}{l}\text { Q2\% } \\
\text { share }\end{array}$ & 42.58 & 7.06 & 22.40 & 27.96 \\
\hline $\begin{array}{l}\text { Q3\% } \\
\text { share }\end{array}$ & 36.74 & 7.08 & 27.19 & 29.00 \\
\hline $\begin{array}{l}\text { Q4\% } \\
\text { share }\end{array}$ & 36.87 & 9.44 & 34.37 & 19.32 \\
\hline \multirow{2}{*}{$\begin{array}{l}\text { Q5\% } \\
\text { share }\end{array}$} & 27.77 & 19.86 & 40.30 & 12.08 \\
\hline & $\begin{array}{l}\text { Average household } \\
\text { members }\end{array}$ & $\begin{array}{l}\text { Average number of members } \\
\text { working }\end{array}$ & $\begin{array}{c}\% \text { homeowner } \\
(\%)\end{array}$ & $\begin{array}{c}\% \text { holding financial } \\
\text { assets } \\
(\%)\end{array}$ \\
\hline $\begin{array}{l}\text { Q1\% } \\
\text { share }\end{array}$ & 0.9128 & 2.4680 & 28.95 & 21.49 \\
\hline $\begin{array}{l}\text { Q2\% } \\
\text { share }\end{array}$ & 0.8820 & 2.4234 & 86.07 & 37.19 \\
\hline $\begin{array}{l}\text { Q3\% } \\
\text { share }\end{array}$ & 0.8552 & 2.4661 & 95.91 & 50.74 \\
\hline $\begin{array}{l}\text { Q4\% } \\
\text { share }\end{array}$ & 0.8876 & 2.4529 & 95.36 & 59.75 \\
\hline $\begin{array}{l}\text { Q5\% } \\
\text { share }\end{array}$ & 1.0240 & 2.6203 & 95.46 & 81.59 \\
\hline
\end{tabular}

Table AI.

Socio-demographic characteristics of households by net wealth quintile, 2014 


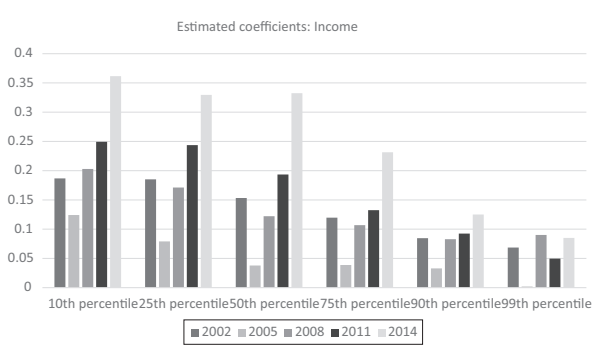

(a)

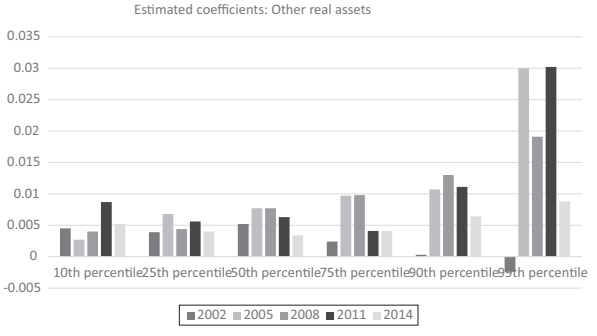

(c)

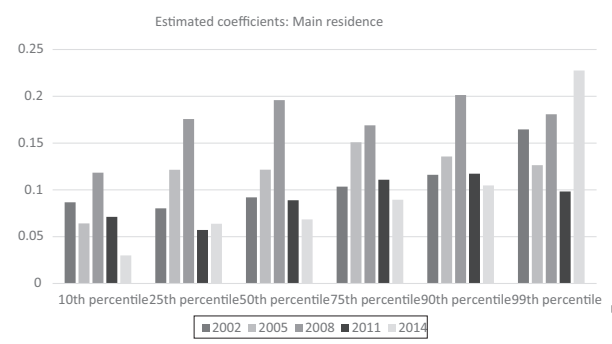

(b)

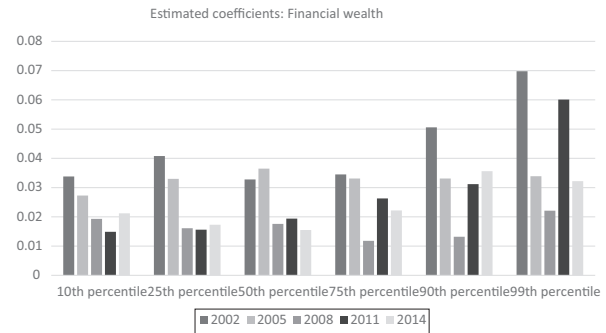

(d)

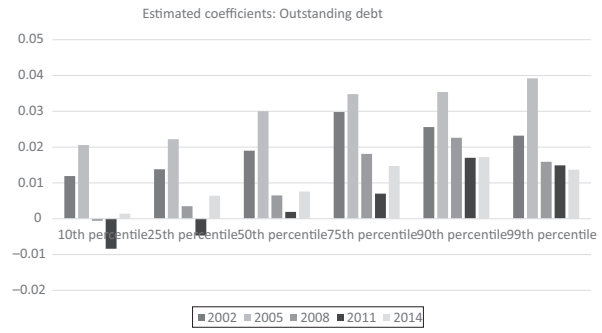

(e)

Notes: (a) Estimated coefficients: income; (b) estimated coefficients: main residence;

(c) estimated coefficients: other real estates; (d) estimated coefficients: financial wealth;

(e) estimated coefficients: outstanding debt

Figure A1. Total consumption interquantile regression estimates, 2002-2014

\section{Corresponding author}

Juan Ignacio Martín-Legendre can be contacted at: juan.ignacio.martin.legendre@udc.es

For instructions on how to order reprints of this article, please visit our website: www.emeraldgrouppublishing.com/licensing/reprints.htm Or contact us for further details: permissions@emeraldinsight.com 